\title{
III. 香気成分の動物応答
}

\section{小野武年, 田㴊英一 \\ 富山医科薬科大学医学部第二生理学教室}

ヒトや動物は, 本能 (摂食, 飲水, 性, 体温調節, 集 団行動）扣よび情動行動（快情動行動; 接近行動, 不快 情動行動; 逃避や攻撃行動）によって，自己の保存括よ び種族の維持と繁栄を確保している.これら本能および 情動行動の動機づけから確実な遂行に至るまでには, 内 部環境だけでなく, 外部罢境からの特殊感覚系 (視, 聴, 嗅掞よび味覚) および体性感覚系（温，冷，触，圧およ び痛覚）からの情報の認知が不可欠である．

最近, 各種感覚, とくに視覚や聴覚による認知や記憶 の脳内機構に関して, 動物行動学や生態学加らニューロ ンレベルでの研究により多くのことが明らかにされつつ ある(1 4). しかし，嗅覚に関する行動については研究例 が少ないだけでなく，基礎となる各種動物に対しての快 臭 (報酬)または不快臭 (罰)や動物の種特異的な匂い嗜 好珄についての系統的な研究も十分ではない.この理由 として, 嗅覚の研究では, 刺激の強さ, 時間执よび変化 要素 (刺激の 3 要素) を正確に設定できず，刺激に対す る応答潜時や刺激の程度と応答の大小（容量一反応）の 関係など，定量的な解析が技術的に困難であったことも 一因であろう。しかし, 最近の医用電子工学やュンピュ 一タ技術の飛躍的な進歩により，工夫をすれば嗅覚に関 する定量的な研究も可能になってきている.

本稿では，まず動物やとトに和ける嗅覚の生物学的役 割や特殊性について簡単に述べ，次いで，最近筆者らが ラットで進めている食品関連の匂い嗜好性に関する行 動 $^{(5)}$ 执よびニニーロンレベルでの研究(6)について紹介す る。

\section{嗅覚の生物学的役割および特殊性}

動物の世界では，嗅覚は，自己保存および種族維持に 不可欠な本能㧍よび情動行動の遂行に最も重要な感覚の 一つである(7). 自己保存のためには，食物となる他の動
物を襲って捕らえたり，食べごろの果物などをとったり して食べるが，その祭，嗅覚によって食物の存在を探知 して接近する。また，手に入れた食物の美味しさ，消化 や栄養価の良否，さらには有害かどらかの判定も专の包 いを嗅いで行なう，他の動物の匂いを感じたとき，それ が仲間か敵か，無害な動物か、，どの程度の距離にいるの かなどを嗅ぎわけ，敵ならば最も安全なところに早く逃 げるなどの対応をする。

種族維持のためには，成熟した雄と雌が互いに自己に 最適な異性の相手を見つけ，性的結合によって子孫を残 すために必死の努力をする。この際にも嗅覚が力強い武 器となる. 1 年のごく短い限られた時期 (交尾期) （例：イヌ, 春秋; ヤギ, 秋; サル, 冬) に最適な相手を 見つけるのは容易でなく, 視覚や聴覚は役に立たないこ とが多いある種の動物は，特殊な匂い(フェロモン) を発して異性の相手に自己の存在を知らせ，出逢いを確 実にする、フェロモンは，単独生活をする動物だけでな く，集団生活をする動物でも，集団の中での親子の認知 や記憶, 多数の雌の中でどの雌が発情しているかる認知 することなどに重要な役割を果たしている.さらに，動 物は自己が生活圈とする領域の境界線にフェロモンをつ け, 自分の縄張りを明示し, 自己の生活の安全を図る.

ヒトの生活の中では, 視覚や㯖覚が本能や情動行動の 確実な遂行にきわめて大きな役割を果たしているため， 嗅覚はむしろ忘れられた感覚としてとり上げられないこ とが多い、乙かて，特別な包い，たと光ば腐った包い， ガスの匂い, 焦げ臭い旬いなどに詨しては，本能的に敏 感で，食物中毒，ガス中毒，火事などから身を守ってい ることは日常の経験からるわかる. また人間にとって, 衣・食・住の中でも美味しい食事は最大の関心事でむ る. “美味しさ”，すなわら食品の嗜好性は，口の中に入 った食物から受けとる総合された口腔内感覚の認知によ 
るものであり，包い，味，歯ざわり，風味などの広義の フレーバーにより認知される.とくに，特定の食物が口 腔内の感覚受容器を直接刺激して赀好性を形成するの は，狭義のフレーバーとしての香り（匂い）と味の $2 つ$ である，食品の加熱香気，果物・醸造品の完熟香などの 匂いは，味覚物質とは比較にならない活ど少量である が，口に入るはるか前から嗅覚器官を刺激し，栄養素・ 味覚物質の存在を一瞬のうちに判断するのに役立ってい る ${ }^{(8)}$.このように, 嗅覚の機能は, 他の感覚では代用で きない重要なものである.

種特異的な，特定の包いに対する嗜好性についてはい
下部外側野の順で処理・統合され，本能および情動行動 の発現に至ることが示唆されている.しかし，食物・非 食物の嗅覚性認知については，匂い嗜好性に関する行動 学的データの収集方法さ光確立していないのが現状であ る. 最近, 筆者らはマイコン制御方式により、ラットが レバー押しによりスプレーに充填された8種類の匂いを 自由に選択して噴霧できる装置を開発した。この装置を 用いて，レバー押し回数の経時的变化を記録し，ラット の食品関連の匂い嗜好性を定量的汇調べている(5).

図 1 飞は，匂小嗜好性決定装置と飼育ヶージの模式 図（A）およびデータ計測中のディスプレイ表示モード

くつかの報告がある，それらは，主 に有益な匂いに近づく行動（接近行 動）之有害な匂いから遠ざかる行動 （逃避行動）とに分類できる，接近 行動の例としては，雄と雌の金魚は フェロモンの一種であるプロスタグ ランディン Fへの曝露により, 血液 中の性フェロモンが増加して性行動 (spawning) を起こすことが知られ ている(9)。また，ラットの乳児は嗅 球の切除により, 母親の乳首に近づ く行動ができなくなり死ぬことさ兄 ある(10). 逃避行動の例としては，サ ンショウウオの幼生が, 敵の魚から 放出される化学物質を嫌うことなど が挙げられる(11).これらのことか ら, 動物にはある種の匂い，とくに 自己保存や種族維持関わる匂いに ついては, 種に特有な遺伝的に備わ った包い嗜好性があることが示唆さ れる(12).

\section{ラットの食品関連の匂い嗜好性}

ラットやサルでは, 視覚や聴覚性 認知に基づく食物と非食物の識別に 関与する脳内部位についてのニュー ロンレベルでの研究報告がある.と くに,サルでの実験により ${ }^{(2 \sim 4)}$, 食物 と非食物の視覚性認知は, 大脳皮質 視覚野 $\rightarrow$ 下側頭皮質 $\rightarrow$ 扁桃体 $\rightarrow$ 視床

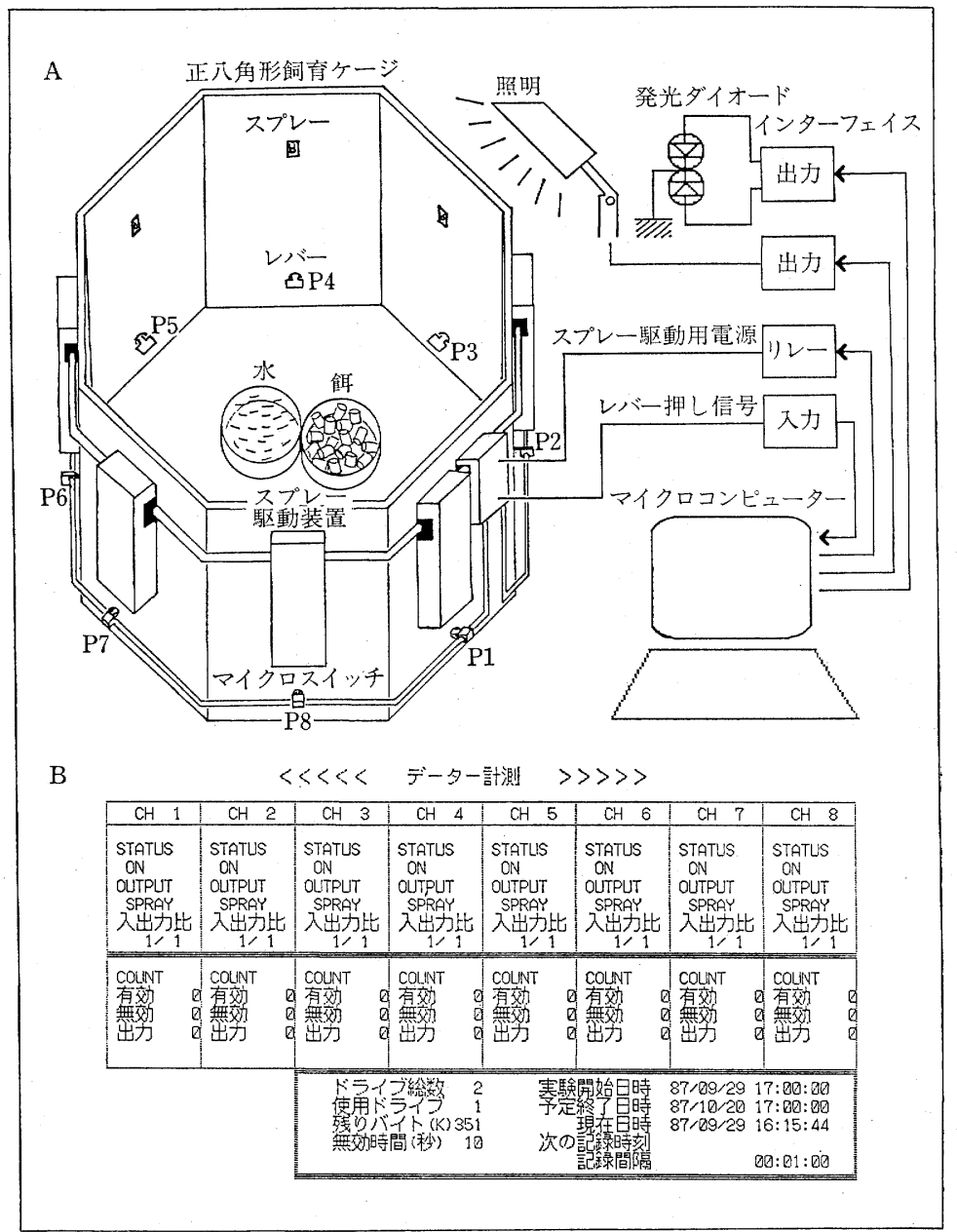

図 1⿴囗十匂い嗜好性決定装置と飼育ヶージの模式図 (A) およびデータ計測中 のディスプレイ表示モード（B）

$\mathrm{A}$ : ラットが任意のレバーを押すとその信号がパソコンに入力され, 発光ダイオード の発光と同時に，その場所のスプレーから勾いが噴霧する. ラットは中央の容器内の慨 や水を自由に摂取できる. P 1 P 8 は各レバーの位置.

$\mathrm{B}$ : 各チャンネルのレバー押し回数，実験開始日時，明暗周期などの設定条件はすべて パソコンにより行なった. 
（B）を示した. 飼育ヶージの形状 は正八角形とし，各壁にはレバーと スプレーを1対ずり設置してある。

天井には脱臭のためのファンを設置 乙，常時回転させて換気を行な觉る ようにしてある.このような飼育ヶ 一ジ内で, ラットは自由に摂食や飲 水ができ，任意のレバーを押すと， その場所のスプレーから各々の包い が噴霧する，スプレーから包いが噴 霧された後, 一定期間 (20 秒) はレ バーを押しても無効とし, 直前に噴 霧された匂いの影響をできるだけ少 なくするよらにしてある、明暗条件 はパソコンにより, 通常 12 時間周 期に設定してある（明期， 9:00〜 $21: 00$; 暗期, $21: 00 \sim 9: 00$ ).

包いとしては，ヒトが身近に経験 する食品関連のチーズ, ミルク，オ レンジ, ナッッ, プラム, コーヒ 一, ペパーミント, ブラックペッパ 一の8 種類を用いた．実験はラット を 1 匹ずつ飼育ケージに入れ， 1 試 行を約 2 週間として 3 試行を連続し て行なった(図 2). また, 各試行ご とに各壁のレバーに対応する勾いを 変え, 場所に関連したレバー押しの 影響を少なくした。ささらに，図 2 の 実験とは別のラットで匂いに対する 暏好性をより明確にするために，正 八角形の飼育ヶージ壁の 8 個のレバ 一を1つ执さに，それぞれ4個をい ずれの匂いも噴霧しないレバー（対 照レバ一) およびブラックペッパー, ント拈よびチーズのいずれかの包いを噴霧するレバー (匂いレバー) としたときの各レバー押し回数も調べた. この実験の結果, ラットの食品関連包い嗜好性は, 主 に(1)ブラックペッパーを比較的嗜好する (タイプI), (2)ミルクやコーヒーを嗜好する (タイプII), (3)すべて の匂いを嗜好し，特定の旬いに対して嗜好性を示さない (タイプIII), (4)いずれの包いも嗜好しない(タイプI)
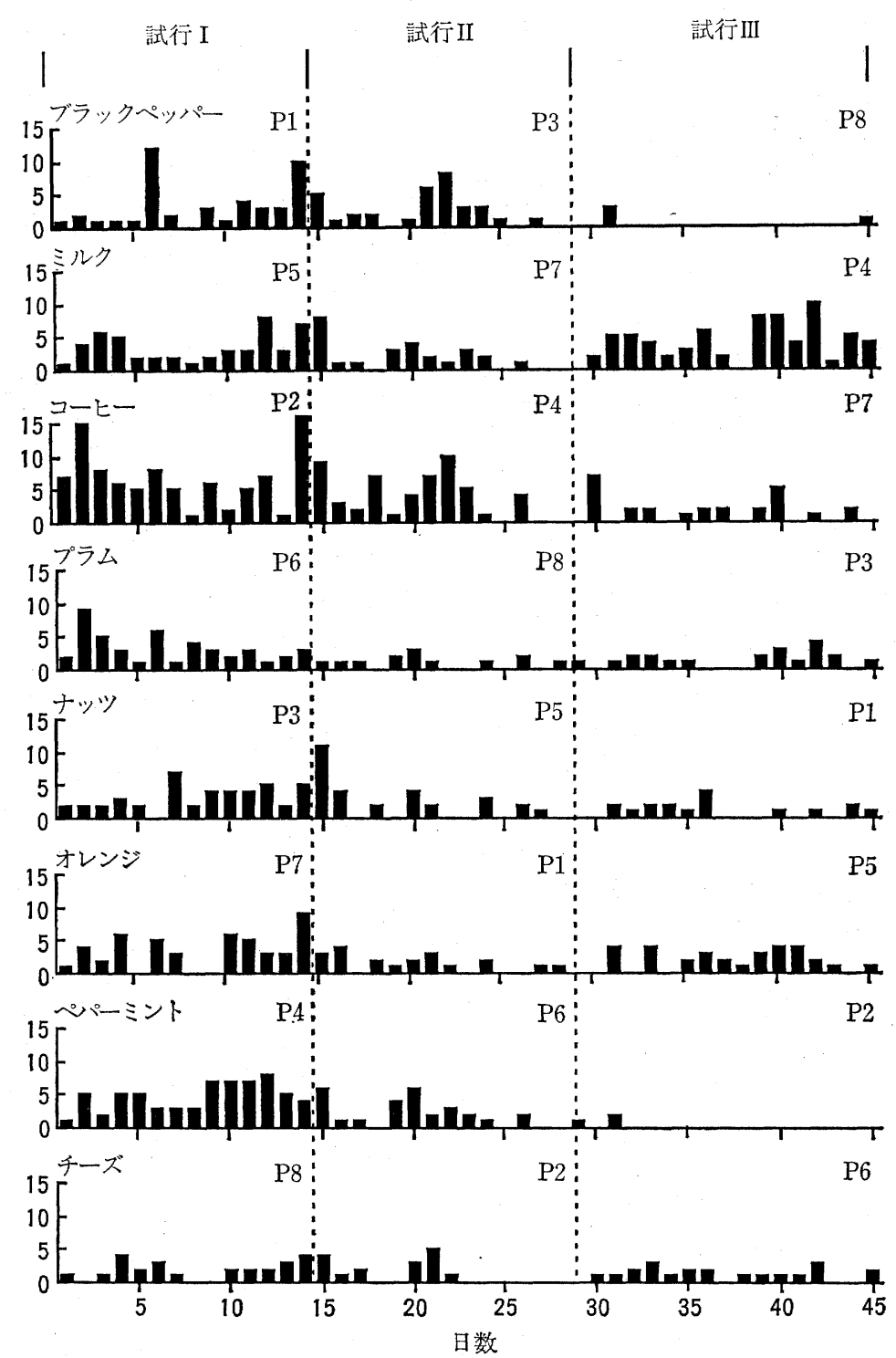

図 2 -3 試行でのラット 1 匹における 1 日ごとの各々の匂いレバー押し回数 のヒストグラムの例

各試行ごとに各壁のレバー（P1～P 8) に対応する匂いを变えてあるが，いずれの試行 においても，ミルクとコーヒーの包いのの赀好性は強く, チーズの包いの嗜好性は 弱い、各垂直の点線は試行IIおよびIIIの開始時点. 

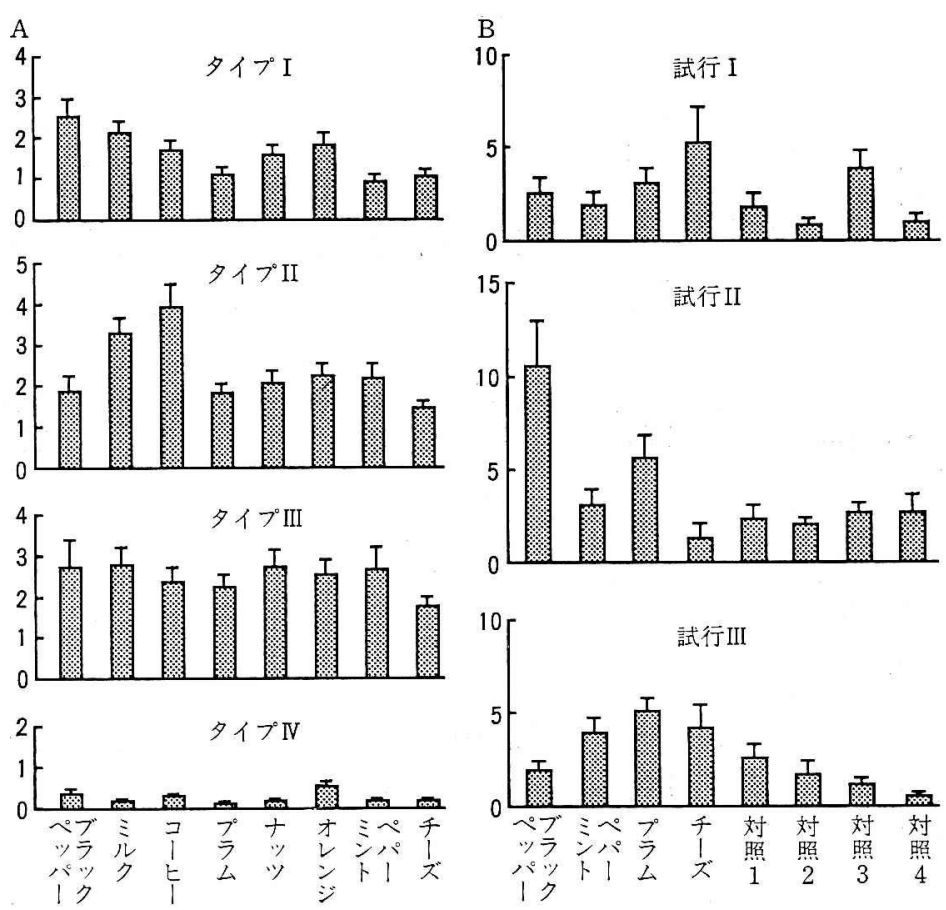

図 3ロタイプ I, II，III，IV ラットにおける食品関連の 8 種類の匂いに対 する 1 日の平均レバー押し回数（A）および飼育ヶージ壁に 1 つおきにそれ ぞれ 4 個の対照レバーと匂いレバーを設置したときの各試行ごとの 1 日平均 レバー押し回数（B）

$\mathrm{A}$ ：ラットの食品関連匂い、嗜好性は，(1)ブラックペッパーを比較的赀好する（タイプ

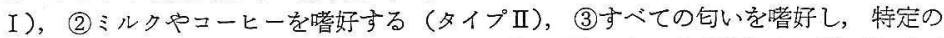
匂いに対して嗜好性を示さない（タイプIII），(4)いずれの句いも嗜好しない群（タイプ IV）の 4 群に大きく分類できた。

B : 試行 I， II，IIIでは，対照レバーと各包いレバーの位置関倸を変えてあるが，いず れの試行でも対照レバーよりも包いレバーを多く押している.

例について，1日の平均レバー押し回数のヒストグラム を示した．特定の包いに対して嗜好性を示したタイプI およびாでは，それぞれブラックペッパーおよびミルク とコーヒーを嗜好したが，タイプIもIIもチーズの匂い への嗜好性は弱い，タイプIIは，すべての匂いにほぼ同 様の嗜好性を示している。 また，タイプIV，いずれの 包い夕莻好していない(いずれの旬いレバーもはとんど 押していない).

図 3-B には，正八角形の飼育ケージ壁の 8 個のレバ 一を1つおきにそそれぞれ4個を対照レバーおよびブラ ックペッパー, プラム, ペパーミント，チーズの旬いレ バーとしたときの各試行に括けるラット 1 匹の 1 日ごと のレバー押し回数のヒストグラムを示した. 試行 I，II， IIIでは, 対照レバーと各匂いレバーの位置関係が変えて あるが，いずれの試行でも対照レバーよりも匂いレバー を多く押している $(p<0.01)$. 図 3-Bから，このラット
は居場所に関係なく対照レバーより も匂いレバーを多く押しているとい える、これらのことから、ラットが ブラックペッパー, プラム, ペパー ミントおよびチーズの包いを嗜好す ることは明らかである

ヒトが日常経験する 8 種類の食品 関連の匂いについての動物の自発的 なレバー押しによる嗼好性テストに より, ラットの場合，(1)少なくとも これら8種類の匂いを自発的に嗅ぎ （嗜好し），ラットによっては特定の 1 つか2つの匂いをより強く嗜好す るタイプ，(2)いずれの勾いもまった く嗜好しないタイプがあることが明 らかとなった.このよらなラットの 匂い嗜好性に対する個体差が，遗伝 によるのか, 経験や学習による記憶 などによるのか，またここでテスト した食品関連の匂いはラットにとっ てどのよらな生物学的意昧があるの かについてはわからない、今後, こ の基礎的な研究成果を，ラットやサ ルでの動物行動学や生態学から=ュ ーロンレベルでの研究, さらにはヒ トの研究に応用し，これらの問題を解く杀ロを見いだす ことを試みる必要がある。

ラット視床下部ニューロンのオレンジおよびグレ ープジュースの匂いと味に対する応答特性

本能行動の中でも，摂食行動の遂行にば，外部感覚情 報（視，聴，味，嗅执よび体性感覚）の処理・統合によ る食物と非食物の認知や，食物の美味しさ，消化の良否 などの正確な認知が必要である．最近，筆者らは主とし てサルで，1）扁桃体には，呈示物体が食物か否かや，好 き（報酬）嫌い（罚）の度合い，すなわち生物学的意味 の大小をインパルス放電頻度にコードする価値評価二= 一ロン，また特定の報酬または罚物体やこ礼らを意味す る音の 1 つだけに応答する認知細胞類似の快または不快 情動発現に関与するニューロンが存在すること年,4，2） 視床下部外側野には，扁桃体の価值評洒や快または不快 
情動発現ニューロンからの情報に基づき報酬と罰を認知 し, 接近または攻撃や逃避行動の誘起に関与するニュー ロンが存在することなどを明らかにした(2)，さらに筆者 らは，ラットでも視床下部外側野にはジュースや脳内自 己刺激 (ICSS) などの報酬と罰（電気ショックや尾部痛 覚刺激など）に識別的に応答するニューロンが存在し， これらのニューロンは報酬・罰を予告する音刺激にも識 別的な条件づけ応答を獲得 (学習)することも報告して いる(6). しかし，視床下部外側野ニューロンの食物の嗅 覚や味覚による認知機構㧍よび条件刺激と報酬や罰との 連合学習に和ける役割についてのニューロンレベルでの 研究は少ない(13).

本研究ではこれらのことを明らかにする目的で，手が かり音弁別による報酬獲得敊よび罰回避行動下でのラッ 卜視床下部外側野ニューロンのオレンジまたはグレープ ジュースの旬いと味に対する学習行動応答性を調べた。

ここではオレンジまたはグレープジュースの匂いと味応 答性についてだけ紹介する.

ラットには，1）前もって ICSS の最も起こりやすい 視床下部外側野後部に ICSS 用電極を植兄込々，2）頭 部を慢性実験装置に固定し，口直前に自動的にチューブ を近づけ，チューブをなめるという同一の行動（リック 行動)によりジュース（オレンジ，グレープ）や水また はICSS のような報酬を獲得 (または摂取)することを 学習させ（図 4-A），3）学習成立後，2秒間の報酬予告 音を認知して同一のリック行動による報酬獲得（図 4B) 行動を学習させた。また、ジュース獲得行動におい ては予告音の代わりに予告光刺激も用いた，このような 学習行動下のラットの視床下部外側野から単一ニューロ ン活動 (インパルス放電) を記録した.ジュース溶液と しては，1）匂いはあるが味のない(旬い溶液)，2）味は あるが包いのない(味溶液)，3）旬い之味のいずれもあ る(匂い・味溶液)の 3 種類のオレンジまたはグレープ の抽出溶液を用いた。

視床下部外側野ニューロンの $28 \%$ はオレンジまたは グレープの包い・味溶液に抑制（インパルス放電頻度の 減少）または促進応答（インパルス放電頻度の增加）を 示した.これら応答ニューロンの大多数は匂い溶液と味 溶液の両方にまたごく少数のニューロンが味溶液だけ に応答し，匂い溶液だけに応答するニューロンはなかっ た. 一般に，視床下部外側野ニューロンの句い溶液へ

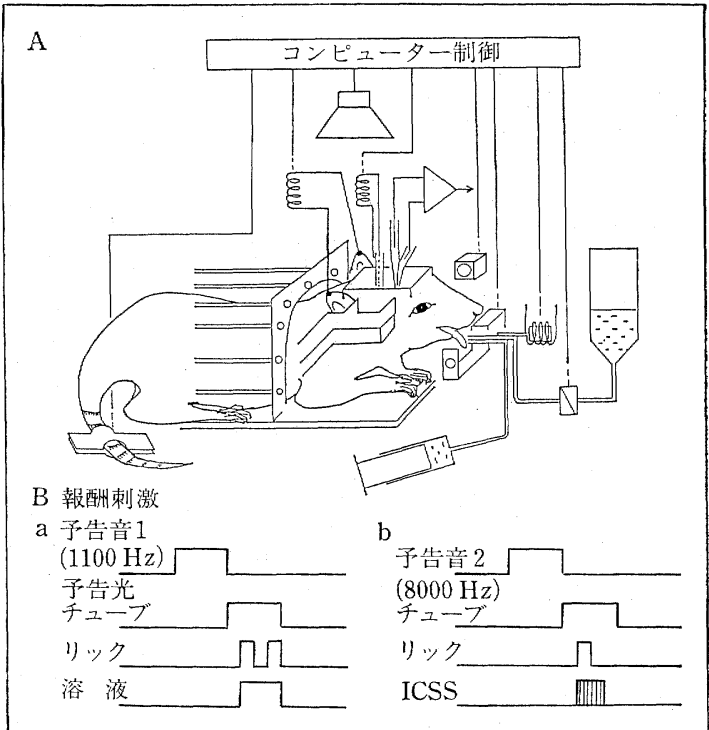

図 4 【ラットの手がかり音または光弁別による報酬獲得 および罰回避学習行動実験の模式図

$\mathrm{A}$ : 報酬としてジュース拉よび 視床下部外側野後部へのICSS を，罰として耳間への電気ショック䑙よび尾部痛覚刺激を用 いた．報酬また虫罚を予告する 4 種類の音刺激は頭上のスピー カーより，予告光刺激は眼前の発光ダイオードより与充た。

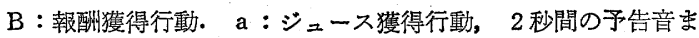
たは光刺激に続いてチニーブから狍い溶液，味溶液または匂い。 味溶液を微量 $(10 \mu \mathrm{l})$ 出乙 (呈示期)，その後チューブを自動的 飞2 秒間，口直前に近づけた。 その間にテニーブをなめる（リ ック)とシュースを獲得できた。 b : ICSS 獲得行動，2秒間 の予告音の後にチニーブをロ直前に近づけ，チューブをなめる と ICSS を獲得できた。

の応答 (図 5-Aa，Ba）と味溶液への応答（図 5-Ab, $\mathrm{Bb}$ ）は同方向で，いずれにも抑制応答（困 5-Ac）また は促進応答 (図 5-Bc) を示した。 旬い溶液への応答潜時 は味溶液への潜時上り短かった $(p<0.01$ ) (図 5-A, B). また, 匂い・味溶液への応答は匂い:溶液への応答と味溶 液への応答の単純な加算であった（図 5-Ac，Bc）.

ジュース予告音への条件づけニューロン応答は，2〜 5 回の試行で包い溶液だけでなく, 味溶液に対しても速 やかに獲得 (学習)され (条件つけ応答獲得), 予告音之 対応するジュース溶液との関係を解消すると，予告音へ の条件応答は数回の試行で消失した（条件づけ応答の消 去). 予告音への条件づけ応答の獲得和よび消去は，条 件づけリック行動の発現敊よび停止と強い相関があっ た. ジュース予告音と同様に, ニューロンの条件づけ応 答の獲得蛙よび消去は予告光刺激についても起こった。

解剖学的には, 嗅覚情報は㖵球から外側嗅索路を通っ て, 視床下部外側野に単シナプス性, あるいは嗅結節抏 


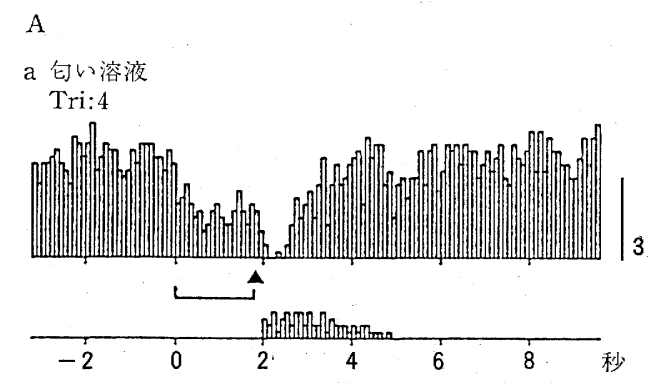

$\mathrm{B}$

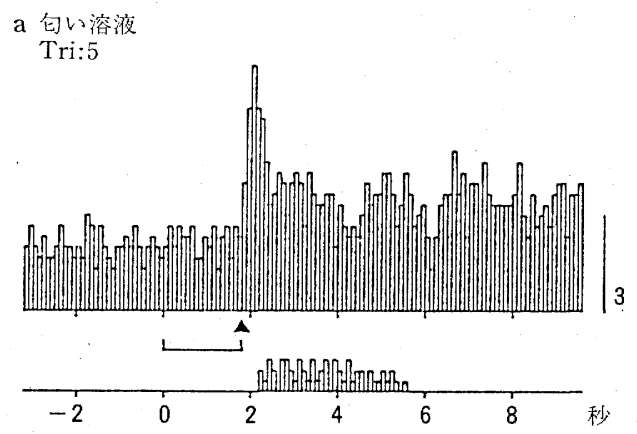

b 味溶液
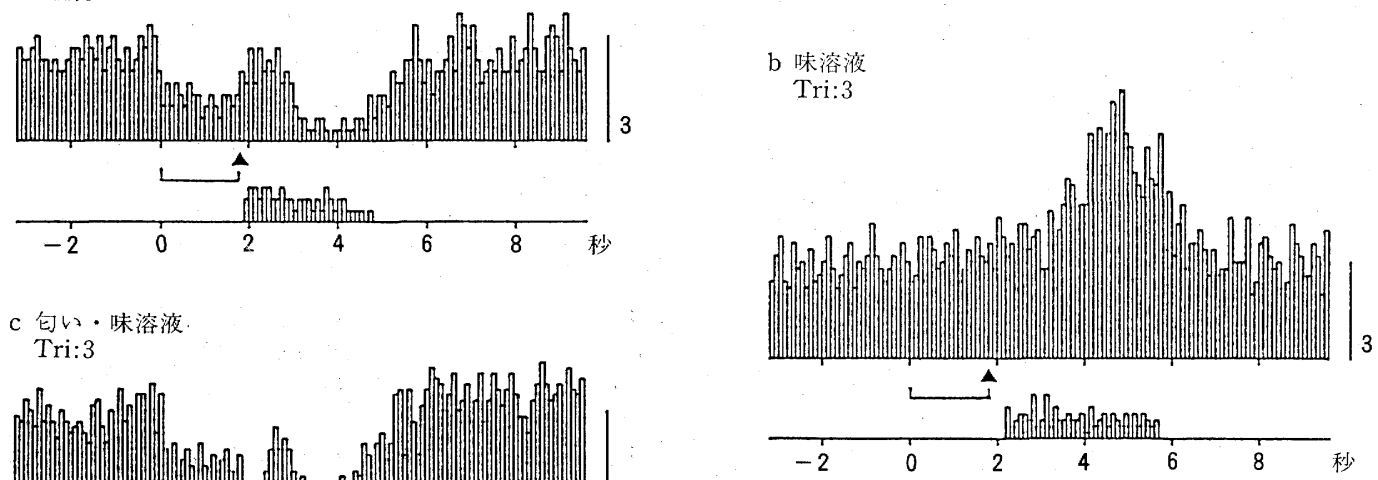

c 匂い・味溶液.

Tri:3

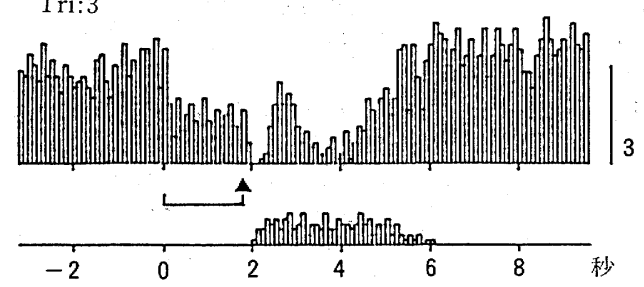

c 匂い・味溶液

Tri:6

d 水

Tri:3
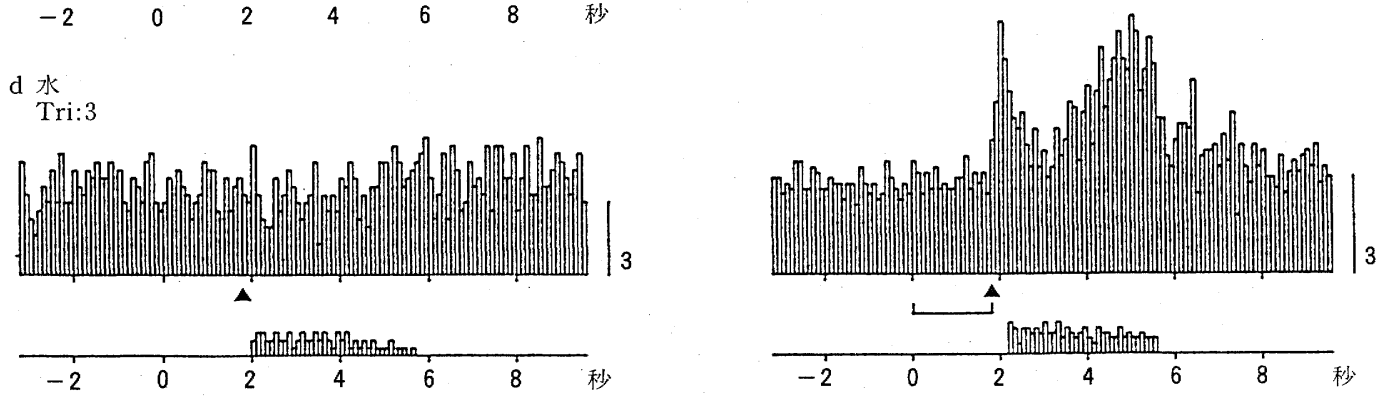

図 5 ロラット視床下部外側野ニューロンの匂い溶液, 味溶液, 匂い・味溶液および予告音または光刺激への抑制 (A) または促進応答 (B)

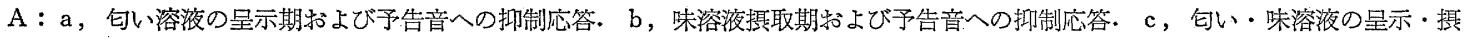
取期虬よび予告音への抑制応答. $\mathrm{d}$ ，水の呈示・摂取期には無応答. B : 予告光には無応答. a ，匂い溶液の呈示期の促進応答. b, 味溶液の摄取期の促進応答. $\mathrm{c}$, 匂い.味溶液の呈示・摄取期の促進応答. Aおよび B : 匂小溶液呈示・摄取期への応答は, 味溶液

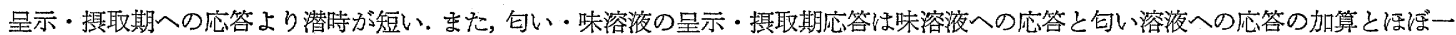
致. い: 予告音の持続時間， $\boldsymbol{\Delta}$ ：チューブを口直前に近つけた時点，ヒストグラム上：加算したニューロン応答，下：リック信号.

よび扁桃体の皮質核，内側核を経由して多シナプス性に 送られる. 一方, 味覚情報は延髄孤束核や橋味覚野から 視床下部外側野，扁桃体中心核に直接または視床や大脳 皮質を経由して送られる．本研究に和けるラット視床下 部外側野のジュース摂取応答ニューロン中には，匂い溶
液と味溶液の両方に応答するニューロンが最も多く, 味 溶液または包い溶液の一方だけに応答するニューロンは ごく少数でほとんどなかった. このことは，ラット視床 下部外側野のジュース摂取応答ニューロンは匂いと味に 関する情報を収束性に受けて叔り，食物の美味しさや良 
否の認知には嗅覚と味覚情報の両方が重要であることを 示㥖する.また，ジュース摂取応答ニューロンの匂い溶 液，味溶液拈よびそれらの予告音刺激への応答は同方向 であった。これらのことから，ジュース摂取応答ニュー ロンは匂い刺激であれ, 味刺激であれ, 刺激の報酬性そ のものに応答し，条件刺激一報酬の連合学習とそれに基 づく行動発現に関与していると考えられる.

な拉，七トが風邪をひくと，食事がうまくないとか， タバコが栗ずいとかよく耳にする。これは, 風邪により 鼻が詰まったり，ウイルス感染により嗅細胞などの嗅粘 膜や粘膜下組織の損傷により，嗅覚系が十分に働かなく なっているからであろら(14).

本稿では, 動物およびヒトに护年覚の生物学的役 割および種特異性について概説した。また，動物の包い 坨好性の定量的・行動学的解析システム, 学習 (情動) 行動下ラットの中枢ニューロンの匂いと味に対する応答 性研究のための特殊実験システム, ラットが食品関連の 匂いを確かに嗜好することや，視床下部外側野のジュー ス応答ニューロンはほとんどすべて包いと味の両方に応 答することについて述べた。

従来，匂いに関する動物実験では，ヒトの主観的尺度 により㫐い物質の選択やデータの解釈がなされてきた. また，ヒトと動物の匂いに関する嗜好性が同じである か，またはどのよらに異なるのかといった科学的な基礎 データは少ない.このよらな状況では, 動物実験による 食物の匂いによる認知之行動発現の脳内機構の解明は困
難である.

現在, 嗅覚による認知・記憶の脳内機構に関する動物 行動学や生態学からニューロンレベルでの研究は遅れて いる.ここで紹介した筆者らの研究が役立つことを願つ て止まない.

謝辞 : 稿を終えるに臨み, 研究開始にあたり貴重な御助言を いただた和茶の水女子大学家政学部小林彰夫教授に心から 謝意を表します。また，食品関連の匂いを提供していただいた 高砂香料工業(株)に厭く和礼を申し上げます。

\section{文献}

1) T. Ono, K. Nakamura, H. Nishijo \& M. Fukuda : $J$. Neurophysiol., 56(1), 63 (1986).

2) M. Fukuda, T. Ono \& K. Nakamura : J. Neurophysiol., 57(4), 1060 (1987).

3) H. Nishijo, T. Ono \& H. Nishino: J. Neurosci., 8(10), 3556 (1988).

4) H. Nishijo, T. Ono \& H. Nishino: J. Neurosci., 8(10), 3570 (1988).

5) E. Tabuchi, T. Ono, T. Uwano, Y. Takashima \& M. Kawasaki : Brain Res. Bull., in press.

6) K. Nakamura, T. Ono, R. Tamura, M. Indo, Y.Takashima \& M. Kawasaki : Brain Res., 491, 15 (1989).

7) 㗪谷達明, 高木貞敬: “新生理学大系 (9), 感覚の生理学”, 田䐀京二, 小川 哲 (編), 医学書院, 1989, p. 503.

8) 小林彰夫 : 化学と生物, 25(3), 203 (1987).

9) P.W. Sorensen, N.E. Stacey \& K. J. Chamberlain : Horm. Behav., 23, 317 (1989).

10) J. M. Risser \& B. M. Slotnick : Physiol. Behav., 40, 545 (1987).

11) L. B. Kats : Behav. Neural. Biol., 50, 126 (1988).

12) K. Yamazaki, G. K. Beuchamp, J.Bard \& E. A. Boyse : Proc. Natl. Acad. Sci. USA, 86, 9399 (1989).

13) T. Yamamoto, R. Matsuo, Y. Kiyomitsu \& R. Kitamura : Brain Res., 481, 286 (1989).

14) R. L. Doty: Am. J. Otolaryngol., 1(1), 57 (1979).

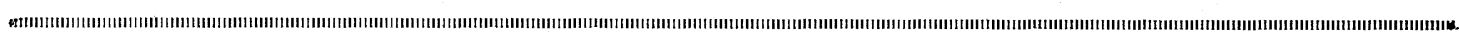

\section{N. 甘味機能調節物質}

\section{栗原良枝}

横浜国立大学教育学部化学教室

各種の基本味のうち, 甘味は栄養学的にも, 食品の味 に特ける貢献度に拈いても, 最も重要な味とされてい る. 従来, 甘味受容機構に関して数多くの研究がなされ てきたが，甘味受容体の実体を含めて，依然として不明 の点が多い、甘味受容機構を解明するためには，甘味受 容体に作用する物質は有用な武器となる。甘味受容体に 作用する物質としては，甘味物質そのもの，甘味を阻害
する物質，甘味物質以外の物質によって甘味が誘導さ れるように味覚機能を修飾する物質などが知られてい る(1 4). 本稿では, これらの物質の構造とその作用関 する最近の進歩を紹介する。

\section{ギムネマ酸（甘味阻害物質）}

ギムネマ・シルベスタ (Gymnema sylvestre, R. Br.) 